\title{
Bioproducts and Homeopathy in Lasiodiplodia Rot (Lasiodiplodia sp.) Control and Development of Passion Fruit Seedlings
}

\author{
Rogelho Alexandre Trento, Solange Maria Bonaldo \\ UFMT/PPGA, Brazil \\ Carmen Wobeto \\ UFMT/PPGCAM, Brazil
}

Marcio Roggia Zanuzo

UFMT/PPGA, Brazil

Juliana da Silva Agostini

UFMT, Brazil

Daniela Ribeiro

UEM, Brazil

Received: December 2, 2020

Accepted: February 21, 2021

Published: March 14, 2021

doi:10.5296/jas.v9i2.18018

URL: https://doi.org/10.5296/jas.v9i2.18018

\begin{abstract}
The aim of this study was to evaluate the effects of homeopathic medicine Calcarea carbonica $12 \mathrm{CH}$ and bioproducts: filtrates of saprobic fungi from Amazon, green propolis nosode $06 \mathrm{CH}$, filtrate of Pichia sp., green propolis extract, Bacillus subtilis; to control Lasiodiplodia (Lasiodiplodia sp.) and development of passion fruit seedlings (Passiflora edulis Sims f. flavicarpa Degener). The experiment was carried out in a completely randomized design with 10 treatments in a parcel divided in time. Each plot consisted of 5 plants for analysis. Data were subjected to analysis of variance and when significant compared by Scott-Knott test ( $\mathrm{p}>0.05)$. Variables related to plant growth and the area under
\end{abstract}


the disease progress curve (AUDPC) were evaluated. Assessments were performed at 67, 74 and 82 days after transplantation. There was no reduction in AUDPC for treatments compared to control. As for plant height $(\mathrm{cm})$, the best treatments were Pichia sp. and Gonytrichum sp. with an increase in relation to control of $29.70 \%$ and $18.24 \%$, respectively, and increased leaf area $\left(\mathrm{cm}^{2}\right)$ by $27.42 \%$ and $19.85 \%$, respectively. B. subtilis, Pichia sp. and Gonytrichum sp., increased total biomass by $42.31 \%, 32.82 \%$ and $21.44 \%$, respectively. The filtrates application from Pichia sp., Filtrate from Gonytrichum sp., C. carbonica $12 \mathrm{CH}$ and $B$. subtilis provided better performance in the development of passion fruit plants with an increase in the main morphological attributes. The results show that the use of bio products improves the development of seedlings, especially the use of yeast and saprophytic fungi by controlling the biochemical and physiological processes of plants during development.

Keywords: Passiflora edulis, Calcarea carbonica, Pichia sp., Gonytrichum sp

\section{Introduction}

Brazil is the largest producer of passion fruit, and the most cultivated species is Passiflora edulis Sims f. flavicarpa Degener. Planting is encouraged and widespread in family farming where planting areas range from 3 to 5 hectares. However, there is large-scale production with the use of technology to increase yield (IBGE, 2019).

Passion fruit crop is widely distributed in the tropical and subtropical regions of Brazil, totaling an area of 41,584 hectares, in which 593,429 tons of fruits were harvested in 2019. In Mato Grosso, the planted area covers 282 hectares, yielding 4,625 tons, with a production value of $\mathrm{R} \$ 14,454,000.00$ (IBGE, 2019).

Production could be increased with the use of robust seedlings in the orchard establishment, that are more resistant to diseases and pests attacks because most of the production losses are related to the two factors, favored by environmental conditions, such as temperatures between $20^{\circ} \mathrm{C}$ and $30^{\circ} \mathrm{C}$ and $60 \%-80 \%$ humidity during the rainy months. In some regions, clay soils with difficult drainage also favor phytopathogens (Costa et al. 2008).

Environmental conditions favor the occurrence of diseases such as anthracnose (Colletotrichum spp.), bacteriosis (Xanthomonas axonopodis pv. passiflorae), Lasiodiplodiablack rot (Lasiodiplodia theobromae), and Fusarium wilt (Fusarium oxysporum f. sp. passiflorae). These are aggressive diseases that may cause plant death in the absence of control (Manicom et al. 2003).

Biological control of diseases, which involves reducing the inoculum density or activities of diseases caused by phytopathogens by the action of one or more organisms other than man (Cook; Baker, 1983), stands out among the methods of alternative disease control in plants. Thus, in recent years, new sources of microorganisms with the potential for bioproducts control have been investigated.

Bioproducts are defined as any product generated in three ways: traditional (Plant extracts, essential oils, botanical products, nutraceuticals, oleochemicals and polyunsaturated fatty acids), by fermentation and enzymatic processes produced by microorganisms (Coutinho, Bomtempo, 2011). 
In this context, saprobic conidial fungi, which can obtain food from dead organic matter, acting on the decomposition, are prominent. These fungi have a characteristic rusticity, allowing them to adapt to the conditions of the environment, and there are no reports that they cause diseases in plants; however, they induce defense mechanisms such as phytoalexins (Solino et al. 2017).

Oliveira et al. (2019) reported the production of volatile compounds by saprobic conidial fungi from the southern Amazon that reduce spore germination, mycelial growth rate, and production of survival structures and inhibit mycelial growth of phytopathogens, indicating their potential for biological control of diseases and promoting plant growth.

The potential of saprobic fungi, such as Phialomyces macrosporus, in disease control has been reported against coffee bacterial blight (Pseudomonas syringae pv. garcae), with a $42 \%$ reduction in disease severity and a $40 \%$ increase in seedling height (Botrel et al. 2018).

Propolis is a substance produced by bees, with antimicrobial, anti-inflammatory, therapeutic, anesthetic, and healing properties (Ghisalberti et al. 1977). Pereira et al. (2008) tested the effects of the propolis extract on the incidence of cercosporiosis and rust in coffee, observed that the incidence of the disease decreased $46 \%$ and $66 \%$, respectively, with the application of the extract in the concentration $16 \%$.

In addition, homeopathy is an alternative to disease and pest control in agriculture. Developed by the German doctor Samuel Hahnemann (1755-1843), homeopathy involves the principle of using dynamic solutions based on animals, plants, mineral substances, and ill tissues (Bonato; Silva, 2003).

In homeopathy, disease or imbalance is not caused by the fungus, bacterium, or virus but by the energy imbalance of the plant in relation to the microorganism (Bonato, 2002). Therefore, the use of homeopathy aims to increase the natural defenses of plants to control plant diseases (Bonato; Silva, 2003), reduce the activities of phytopathogens such as spore germination (Oliveira et al. 2017), and increase plant growth, as observed in tomato plants (Toledo et al. 2015).

The use of homeopathic preparations in agricultural production including organic production is supported by the law (Brasil, 2008). Homeopathy in plants has been applied by producers who are unable to purchase agrochemicals and especially by producers who want alternatives for decision making when planting and caring for their crops (Bonato, 2010).

Thus, this study aimed to evaluate the effects of filtrates of saprobic fungi and Pichia sp. from the Amazon region, homeopathy Calcarea carbonica $12 \mathrm{CH}$, Bacillus subtilis, and green propolis extract on seedling development and control of Lasiodiplodia black rot on passion fruit culture.

\section{Method}

\subsection{Preparation of Seedlings}

Commercial seeds of passion fruit cv. BRS Rubi do Cerrado (P. edulis f. flavicarpa) were 
sown in 200-cell Styrofoam trays containing autoclaved substrate, which were submitted twice at $121^{\circ} \mathrm{C}$ and $1.1 \mathrm{~atm}$ for 1 hour, at a 24-hour interval. Transplantation was performed in polyurethane bags with a capacity of 1 liter when the seedlings showed four true leaves 37 days after planting.

\subsection{Preparation of Treatments}

The saprobic fungi isolates Brachysporiella sp., Ellisembia sp., and Gonytrichum sp. and the yeast Pichia sp. used in this work belong to the fungal collection of the Microbiology/Phytopathology Laboratory of the Federal University of Mato Grosso (UFMT), campus Sinop. These isolates were grown in a potato, dextrose, and agar (PDA) medium and incubated in a growth chamber at $25 \pm 2{ }^{\circ} \mathrm{C}$ in the dark for 7 days. Subsequently, two disks ( 7 $\mathrm{mm}$ ) containing the microorganisms were removed and transferred to Erlenmeyer flasks with $1,000 \mathrm{~mL}$ of potato and dextrose (PD) liquid culture medium sterilized at $121^{\circ} \mathrm{C}$ and $1.1 \mathrm{~atm}$ for 20 minutes and then incubated in B.O.D at $25 \pm 2{ }^{\circ} \mathrm{C}$ in the dark for 20 days. After this period, gauze filtration was performed to separate the mycelium and obtain the filtrates.

Treatments also comprised the commercial product Rizos® Bacillus subtilis isolated UFPEDA 764, distilled water and potato dextrose (PD) culture medium.

\subsection{Preparation of Homeopathies}

Every homeopathic medicine has a potency that is represented according to the scale in which it was produced, can be Hahnemann's centesimal $(\mathrm{CH})$ prepared according to the Hahnemannian method, Hering's decimal (DH) prepared according to the Hahnemannian method, and fifty millesimal (LM) prepared in a continuous flow. The potency is determined by the dynamization process that consists in diluting and suctioning part of the active input into an inert input.

The preparation of homeopathic medicines was carried out in accordance with Brazilian Homeopathic Pharmacopeia, 3rd edition (2011), it is the one that rules how medicines are prepared based on raw materials, inert material used, scale, and preparation methods. For the experiment, the matrix of the drug Calcarea carbonica $05 \mathrm{CH}$ was purchased in a homeopathic pharmacy.

To increase the potency of the homeopathic medicine Calcarea carbonica from 05 to $12 \mathrm{CH}$, dynamization was performed, which consists of a 1: 100 dilution (1 part of the drug to 99 parts of 30\% v / v alcohol) and suction 100 times on a mechanical shaker, with this there is an increase in the potency $05 \mathrm{CH}$ to $06 \mathrm{CH}$, this process was carried out until reaching the potency that was used $12 \mathrm{CH}$. It was used one glass flask of $30 \mathrm{~mL}$ sterile amber was used for each dynamization.

The rosemary green propolis used to prepare the nosode was obtained at the Food Technology Laboratory at UFMT campus Sinop. According to Brazilian homeopathic pharmacopoeia (2011), as green propolis is an insoluble substance, crushing in lactose was carried out until it reached $03 \mathrm{CH}$ and from $04 \mathrm{CH}, 70 \%$ alcohol was used to dynamise it up to 06CH potency. 
Following the centesimal scale, 1 part of the drug to 99 parts of inert input, $0.06 \mathrm{~g}$ of green propolis was weighed to $17.82 \mathrm{~g}$ of lactose, the total amount of lactose was divided into three equal parts, in gral it was tritured one part of green propolis in a part of lactose, scraping, the second part of lactose was added, tritured, scraping, adding the last part of lactose, tritured and scraping, thus obtaining the tritured $01 \mathrm{CH}$. This process is repeated using the tritured 01 $\mathrm{CH}$ material as a drug to obtain the tritured $02 \mathrm{CH}$, up to tritured $03 \mathrm{CH}$.

\subsection{Preparation of Green Propolis Extract}

Crude green propolis originated from rosemary resin (Baccharis dracunculifolia DC) obtained from beekeepers in Minas Gerais state was crushed and kept in amber packaging a freezer at the Food Technology Laboratory of the Federal University of Mato Grosso (UFMT), campus Sinop.

The extract was prepared with $20 \%$ green propolis in $70 \%$ ethanol and agitation in shaking table for 24 hours at $28^{\circ} \mathrm{C}$. Subsequently, the extract was subjected to a water bath at $70^{\circ} \mathrm{C}$ for 30 minutes and then again to stirring for another 24 hours (Park et al. 1998; Cavalcante et al. 2011). Finally, it was filtered and stored in an amber glass under refrigeration. The extract was diluted to $0.8 \%$ with distilled water.

\subsection{Isolation of the Fungus Lasiodiplodia sp. and Inoculation}

The pathogen was directly isolated from an infected stem sample collected in the field and cultivated in Petri dishes containing PDA for 7 days in a growth chamber at $25^{\circ} \pm 2{ }^{\circ} \mathrm{C}$ in the dark. After the identification of the reproductive structures with an optical microscope, a pure culture was obtained in a PDA medium.

At inoculation, performed 60 days after transplantation (DAT) with the aid of a culture medium perforator $(7 \mathrm{~mm}$ of $\varnothing)$, the seedling stem was punctured at $2 \mathrm{~cm}$ from the base. In the perforated site, a mycelium disc of the pathogen $(5 \mathrm{~mm}$ of $\varnothing)$ was placed and fixed with adhesive tape. The inoculated plants were kept in a greenhouse at a controlled temperature of $26 \pm 2^{\circ} \mathrm{C}$ and about $60 \%$ constant humidity and irrigation.

\subsection{Treatments and Applications}

The treatments were as follows: T1-distilled water; T2-20\% PD culture medium; T3-homeopathy Calcarea carbonica $12 \mathrm{CH}$ at 20\%; T4-homeopathy green propolis nosode 6CH at 20\%; T5-filtrate of Brachysporiella sp. at 20\%; T6-filtrate of Ellisembia sp. at 20\%; T7-filtrate of Gonytrichum sp. at 20\%; T8-Bacillus subtilis at 20\%; T9-filtrate of Pichia sp. yeast at $20 \%$; and $\mathrm{T} 10$-extract of propolis to $0.8 \%$.

Four applications of the treatments were performed prior to inoculation of the pathogen at intervals of 15 days; three applications were performed after inoculation, at an interval of 07 days. The application of the treatments was performed to the leaves runoff point, with a 200 $\mathrm{mL}$ solution volume.

The evaluations recorded at 67, 74, and 82 DAT included plant height ( $\mathrm{cm} \mathrm{plant}^{-1}$ ), root length $\left(\mathrm{cm}\right.$ plant $\left.{ }^{-1}\right)$, leaf area $\left(\mathrm{cm}^{2}\right.$ plant $\left.{ }^{-1}\right)$, leaf dry mass $\left(\mathrm{g}\right.$ plant $\left.{ }^{-1}\right)$, stem dry mass $(\mathrm{g}$ 
plant $\left.^{-1}\right)$, root dry mass $\left(\mathrm{g} \mathrm{plant}^{-1}\right)$, and total biomass $\left(\mathrm{g}\right.$ plant $\left.{ }^{-1}\right)$.

The plant height was measured from the base of the plant to the apical meristem. The root length was obtained by destroying the seedlings, removing the substrate with water and measuring the length of the main root. The measurements were performed using a ruler.

The leaf area was obtained using LI-3100C Area Meter ${ }^{\circledR}$ apparatus. To evaluate the dry mass of leaves, stems, and roots, they were stored in paper bags and transferred to a drying oven with forced air circulation at $65{ }^{\circ} \mathrm{C}$ for 72 hours. After drying, the dry weight of the samples was measured.

The evolution of disease was measured every 07 days after inoculation, it was assessed using a measure tape, taking measurements from the inoculation point in the horizontal and vertical plane but discounting the wound diameter $(7 \mathrm{~mm}$ of $\varnothing)$. The data obtained were used to calculate the area under the disease progress curve (AUDPC) (Campbell; Madden, 1990).

\subsection{Experimental design and Statistical Analysis}

The statistical design was completely randomized (CRD) arranged in split plot design 10x3 (ten treatments and 3 periods of evaluation) with 15 replications. Each experimental unit comprised one plant. The first factor corresponded to treatments (distilled water; PD culture medium; Calcarea carbonica homeopathy; green propolis nosode homeopathy; filtrate of Brachysporiella sp.; filtrate of Ellisembia sp.; filtrate of Gonytrichum sp.; B. subtilis; filtrate of yeast Pichia sp; and green propolis extract), and the second factor was the three evaluation periods at 67,74 , and 82 DAT. Three plants were used to evaluate developmental attributes.

The data obtained were analyzed using analysis of variance, and significant results were compared using Scott-Knott test $(\mathrm{p}<0.05)$ using statistical program SISVAR 5.7 (Ferreira, 2019).

\section{Results}

\subsection{Plant Height}

There were significant differences in plant height among treatments and periods of evaluation as well as their interactions (Figure 1). Plant heights under treatment using Pichia sp. and C. carbonica $12 \mathrm{CH}$ were higher than those under other treatments but were not significantly different from each other, with mean heights of 43 and $40 \mathrm{~cm}_{\text {plant }}{ }^{-1}$, respectively.

The three periods analyzed, treatments with Pichia sp. (increase plant height of $28.59 \%$ compared with control), C. carbonica $12 \mathrm{CH}$ (22.28\%), B. subtilis (21.25\%), Gonytrichum sp. $(17.61 \%)$, and green propolis nosodium $06 \mathrm{CH}(14.62 \%)$ were superior to the other treatments. In first evaluation at 67 DAT, treatments that showed increments in plant height compared with control were B. subtilis (36.89\%), green propolis nosodium $06 \mathrm{CH}(35.71 \%)$, and Pichia sp. $(22.61 \%)$. 


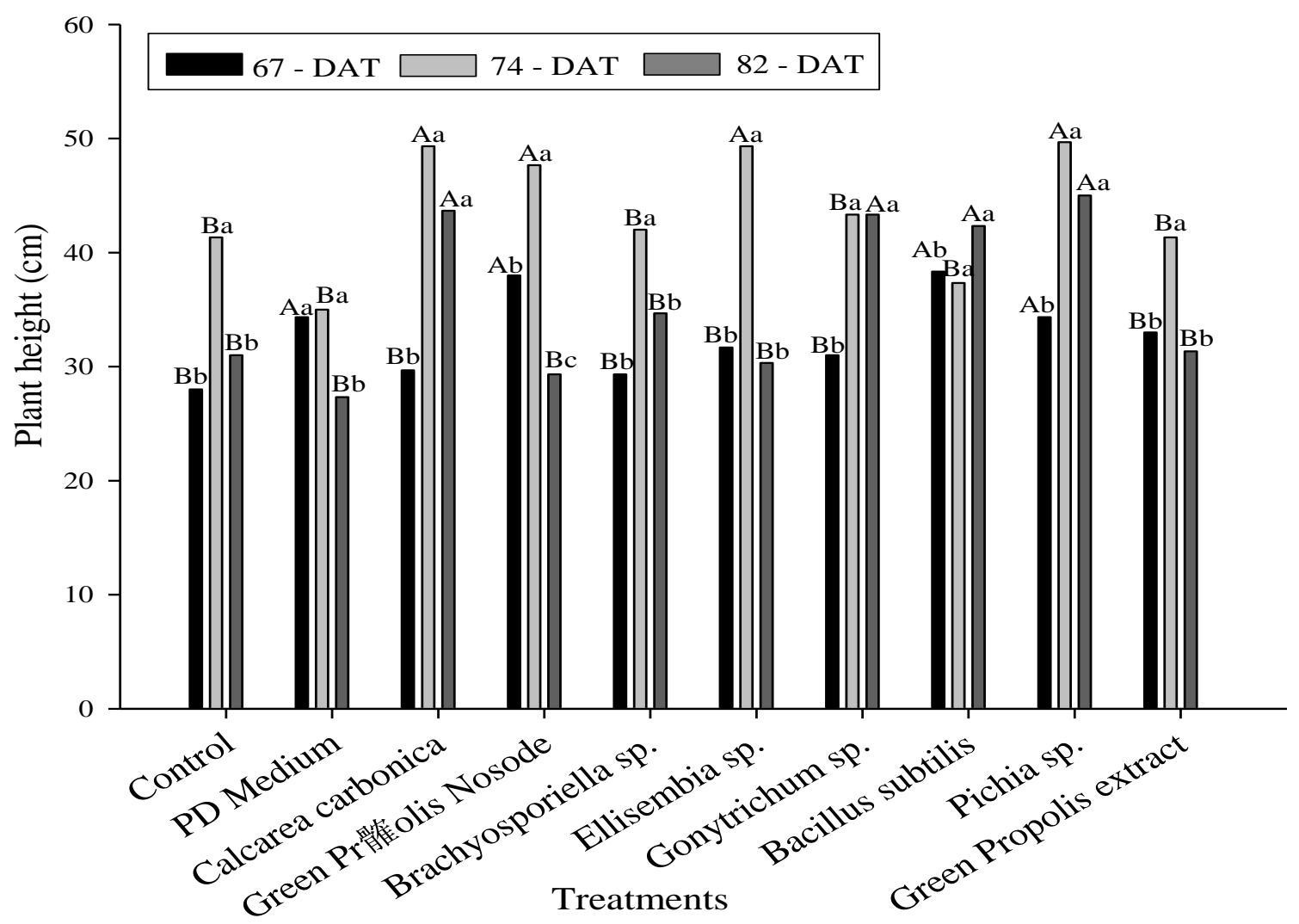

Figure 1. Plant heights(cm) of passion fruit at 67, 74, and 82 (DAT), depending on the application of bioproducts. Distinct capital letter indicate difference $(p<0,05)$ among the treatments in each time period. Distinct lower letters indicate difference $(\mathrm{p}<0,05)$ between period for each treatment. $\mathrm{CV}_{\text {treatment"period: }} 8.17 \%$. $\mathrm{CV}_{\text {period*treatment: }} 10.71 \%$

At 74 DAT, Pichia sp. was superior to other treatments with a $20.18 \%$ increase in plant height compared to control. The plant heights under treatments C. carbonica $12 \mathrm{CH}$, Ellisembia sp., and green propolis nosodium $06 \mathrm{CH}$ were lower than Pichia sp. treatment; however, compared with the control, they showed an increase in plant height of $19.36 \%, 19.36 \%$, and $15.34 \%$, respectively.

At 82 DAT, treatments with Pichia sp., C. carbonica 12CH, Gonytrichum sp., and B. subtilis were superior to the other treatments but did not differ significantly from each other, and increases in plant heights were $45.16 \%, 40.87 \%, 39.77 \%$, and $36.55 \%$, respectively, compared with the control. However, plant heights under treatments with green propolis extract, Ellisembia sp., Brachysporiella sp., green propolis nosodium 06CH, and PD medium and the control did not differ from each other.

Regarding plant height, there is a growth stimulus from the influence of the microorganisms Gonytrichum sp., B. subtilis, and Pichia sp., possibly owing to the production of phytohormones, such as auxin, gibberellins, and/or cytokinins that assist in the development of aerial plant parts and in improving the absorption and translocation of nutrients in the plant. Other studies have found that B. subtilis and Gonytrichum sp. help plant growth and development (Zaidi et al. 2006; Gomezjurado et al. 2015). 


\subsection{Leaf Area}

Regarding leaf area, there were significant differences among treatments, evaluations, and interaction between both, treatments behaving differently according to the time of assessment (Figure 2). Treatments with Pichia sp., B. subtilis, Gonytrichum sp. and C. carbonica 12CH were superior to the other treatments with average leaf areas of 518.56, 488.67, 487.56, and $467.22 \mathrm{~cm}^{2}$ plant $^{-1}$, respectively.

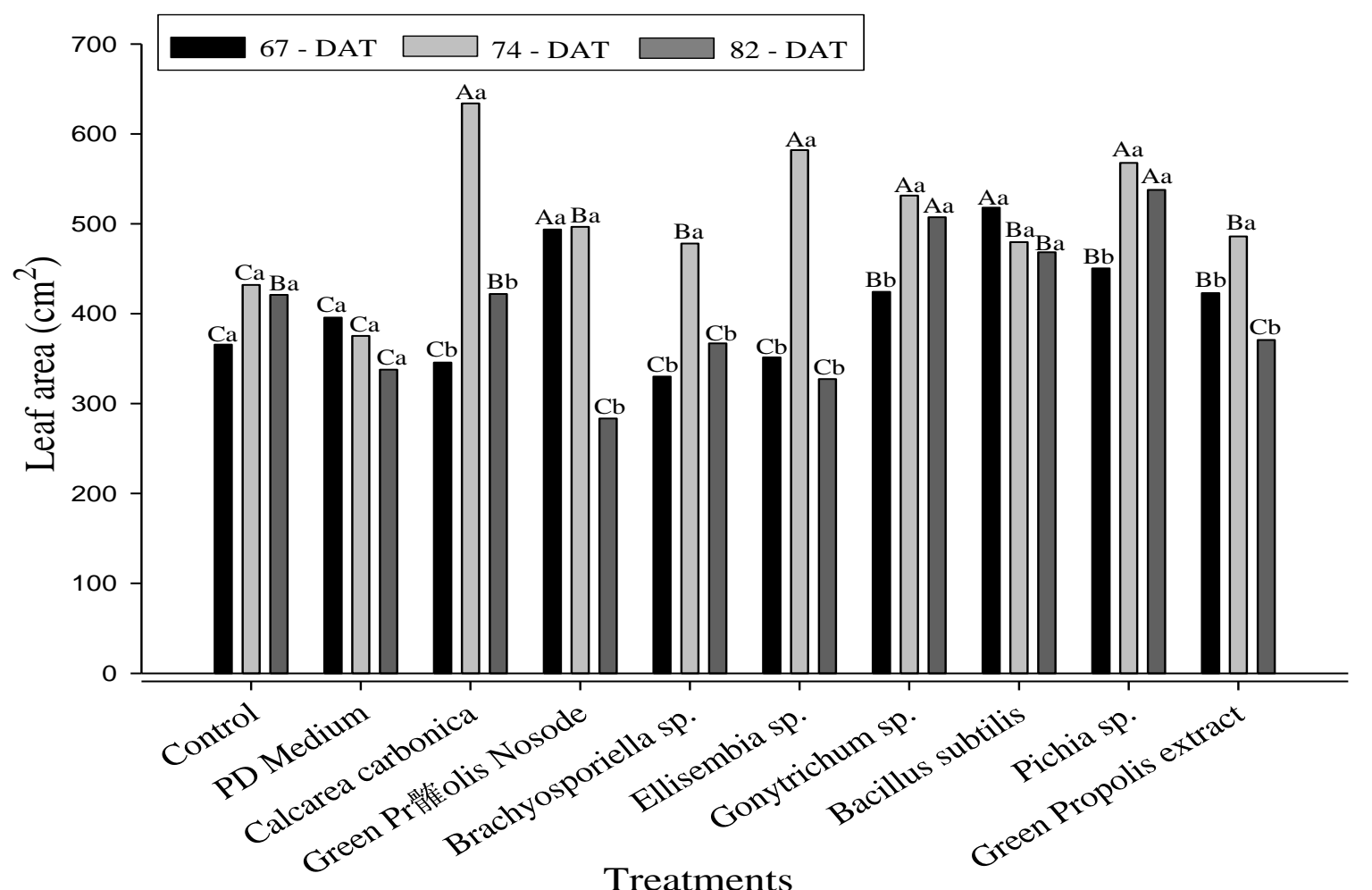

Figure 2. Leaf area $\left(\mathrm{cm}^{2}\right.$ plant $\left.^{-1}\right)$ of passion fruit plants at 67,74 , and 82 (DAT), depending on the application of bioproducts. Distinct capital letter indicate difference $(p<0,05)$ among the treatments in each time period. Distinct lower letters indicate difference $(\mathrm{p}<0,05)$ between

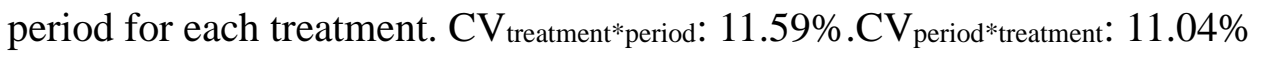

In first evaluation at $67 \mathrm{DAT}$, leaf areas were greater under treatment with propolis nosodium and $B$. subtilis than with others, with average leaf areas of 493.66 and $518.00 \mathrm{~cm}^{2}$ plant $^{-1}$, respectively, providing an increase in leaf area of $41.66 \%$ and $35.01 \%$, respectively, compared to control. Leaf areas under treatment with Gonytrichum sp., Pichia sp., and propolis extract did not differ from each other at $67 \mathrm{DAT}$, and compared to control, there was an increase in leaf area of $16.04 \%, 23.16 \%$, and $15.68 \%$, respectively.

At 74 DAT, a different behavior was observed compared with the previous period. The highest leaf area means were observed under treatments with $C$. carbonica $12 \mathrm{CH}$, Ellisembia sp., Gonytrichum sp., and Pichia sp. (634.00, 582.00, 531.33 and $567.66 \mathrm{~cm}^{2}$ plant $^{-1}$, respectively), and compared to control, there was an increase of $46.76 \%, 34.72 \%, 23.00 \%$, and $31.40 \%$, respectively. 
At this DAT, treatments with green propolis nosodium $06 \mathrm{CH}$, Brachysporiella sp., B. subtilis, and green propolis extract showed leaf area means of 496.66, 478.00, 479.66 and $486.00 \mathrm{~cm}^{2}$ plant $^{-1}$ and an increase of $14.97 \%, 10.65 \%, 11.03 \%$, and $12.50 \%$, respectively, compared with the control.

In third evaluation period at 82 DAT, treatments with Pichia sp. and Gonytrichum sp. were superior to the other treatments with leaf area means of 537.66 and $507.33 \mathrm{~cm}^{2}$ plant $^{-1}$, respectively, and the increase of leaf area shown by these treatments compared with the control was $27.71 \%$ and $20.51 \%$, respectively. Leaf area under treatments with $C$. carbonica $12 \mathrm{CH}$ and B. subtilis did not differ from the control.

Analyzing the results of the leaf area, it appears that Pichia sp., B. subtilis, Gonytrichum sp. and $C$. carbonica $12 \mathrm{CH}$ are promising for this variable, which may result in better use of the light and improve the performance of the biochemical and physiological mechanisms of the plant. The observed increase may be related to the production of phytohormones. In case of Gonytrichum sp., its effect on growth may be related to the solubilization of phosphates, as observed in the study by Gomezjurado et al. (2015), who reported that G. macrocladum had the potential to solubilize calcium phosphate and stimulate plant growth and development.

\subsection{Dry Leaf Mass}

Regarding dry leaf mass variable, there were significant differences among treatments, among periods of evaluation, and interaction between both (Figure 3). Of the three periods analyzed, only in the second period there was a difference in dry leaf mass compared with the control, but when overall evaluation was performed for the three periods, the treatments that produced the best results were Pichia sp., B. subtilis, Gonytrichum sp., C. carbonica 12CH, and green propolis nosodium $06 \mathrm{CH}$, with mean increments of $27.79 \%, 24.60 \%, 22.29 \%$, $13.90 \%$, and $13.60 \%$, respectively.

At the 67 DAT, dry leaf mass under treatment with $B$. subtilis, green propolis nosodium $06 \mathrm{CH}$, Pichia sp., and green propolis extract did not differ from the control. However, at 74 DAT, treatments C. carbonica $12 \mathrm{CH}$, Ellisembia sp., Pichia sp. and Gonytrichum sp. were superior to the other treatments, and compared with the control, they resulted in an increase

of dry leaf mass of $75.19 \%, 75.19 \%, 50.38 \%$, and 50.38\%, respectively (Figure 3). There were no differences among treatments with $B$. subtilis, green propolis extract, green propolis nosodium $06 \mathrm{CH}$, and the control. 


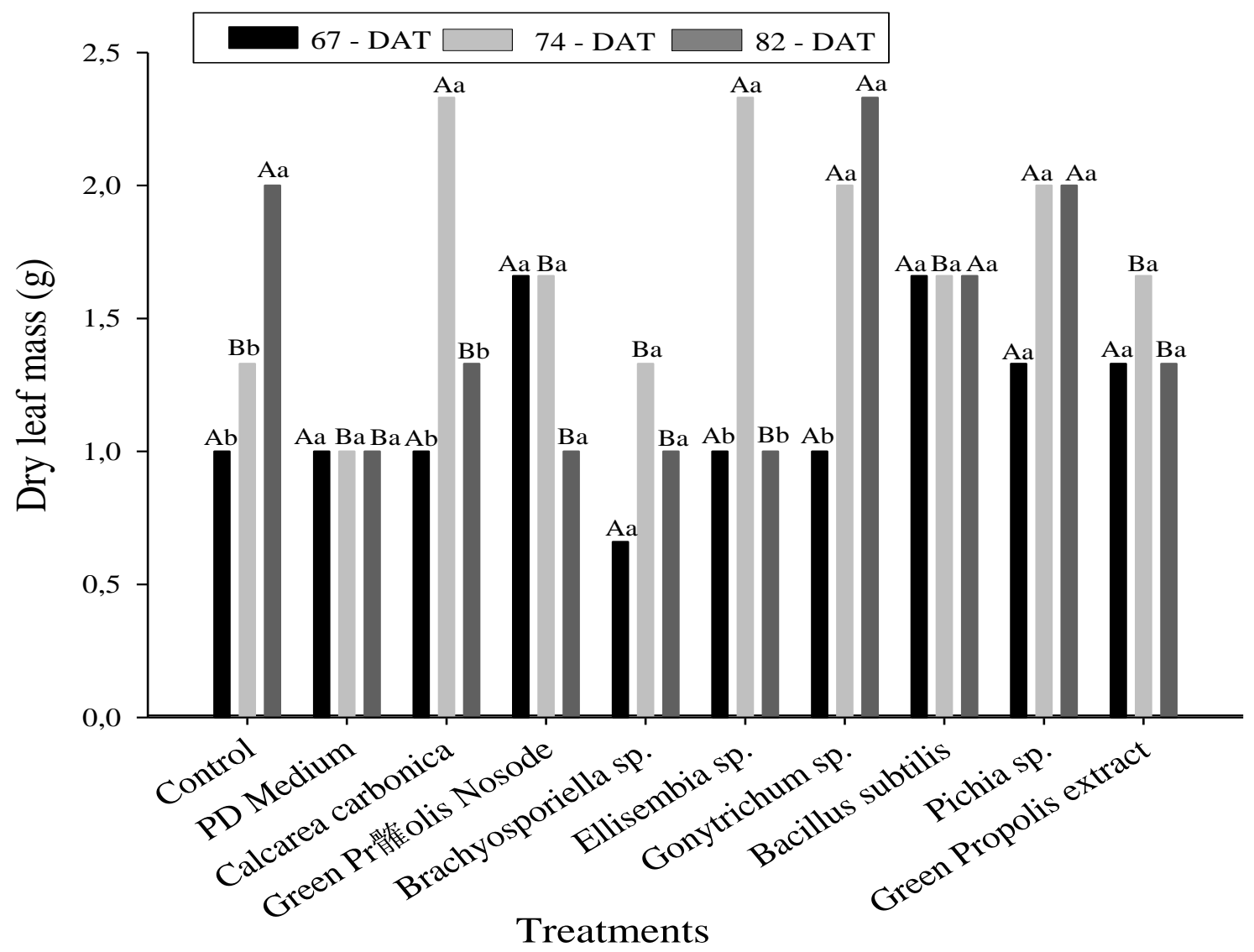

Figure 3. Dry mass (g) of passion fruit leaves at 67, 74, and 82 (DAT), depending on the application of bioproducts. Distinct capital letter indicate difference $(p<0,05)$ among the treatments in each time period. Distinct lower letters indicate difference $(p<0,05)$ between

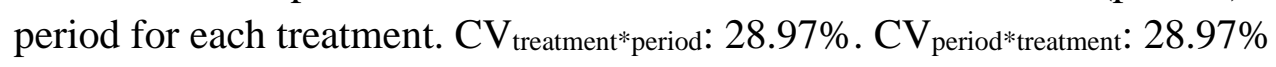

At 82 DAT, treatment with Gonytrichum sp. and Pichia sp. did not differ from the control, and it was observed that only in the second evaluation period there was a difference when compared with the control.

The increments of dry leaf mass (Figure 3) agree with those of leaf areas (Figure 2), with the same treatments presenting better results in both variables when the overall mean was analyzed.

\subsubsection{Stem Dry Mass}

Significant differences regarding stem dry mass were observed among treatments, evaluation periods, and their interaction (Figure 4). 


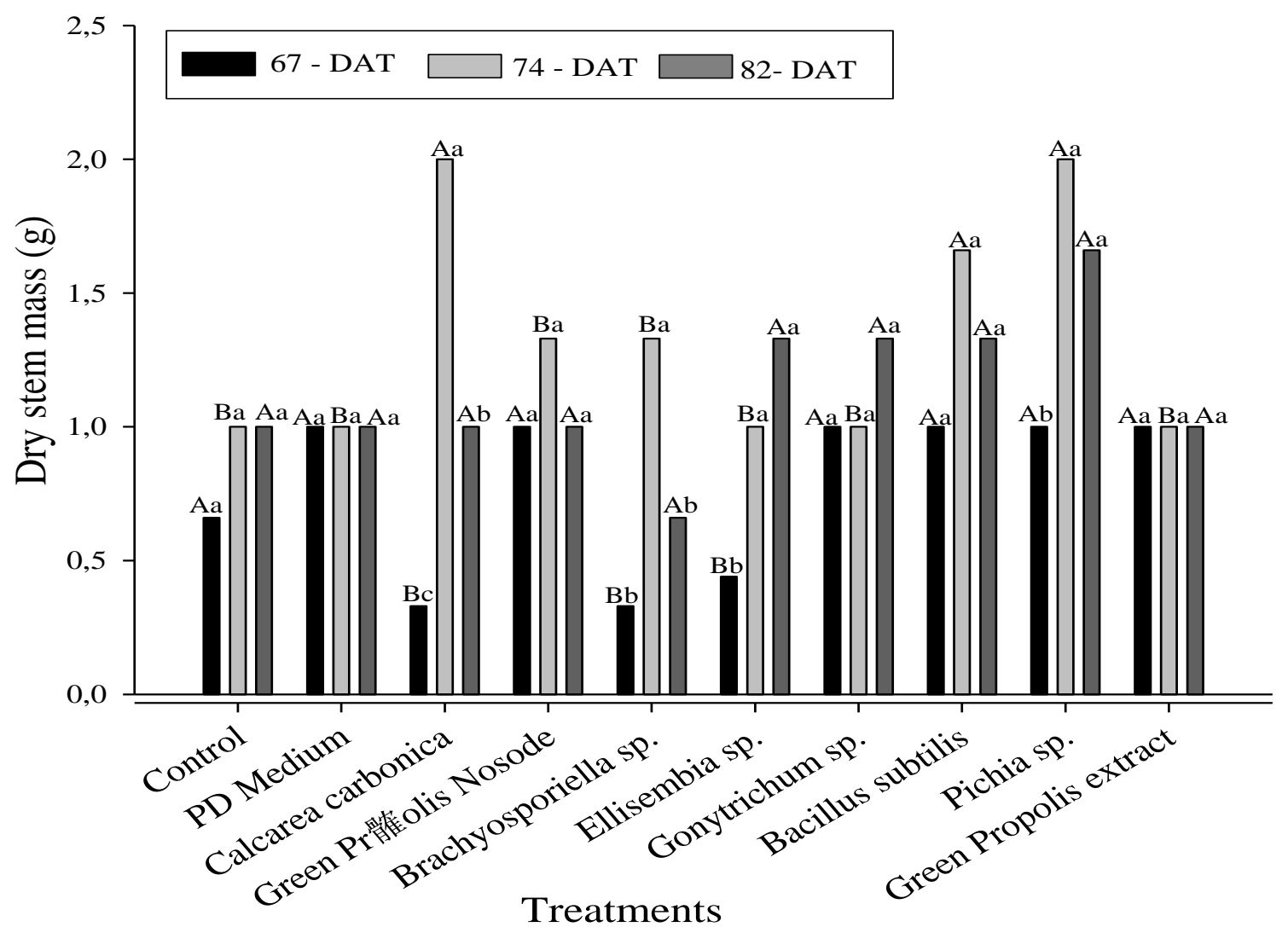

Figure 4. Dry mass (g) of passion fruit stems at 67, 74, and 82 (DAT), depending on the application of bioproducts. Distinct capital letter indicate difference $(p<0,05)$ among the treatments in each time period. Distinct lower letters indicate difference $(p<0,05)$ between

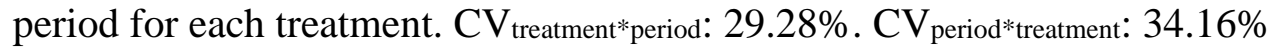

At 67 DAT, treatments with B. subtilis, green propolis nosodium 06CH, Pichia sp., Gonytrichum sp., PD culture medium, green propolis extract, and control did not differ from each other. At 74 DAT, treatments with C. carbonica. $12 \mathrm{CH}$, B. subtilis, and Pichia sp. were significantly superior to the other treatments, with an increase of dry stem mass of $100.00 \%$, $100.00 \%$, and $66.00 \%$, respectively, compared with the control; however, other treatments did not differ from each other.

At 82 DAT, there were no significant differences compared with the control. In general, the mean increments in dry stem mass according to the evaluations were $72.51 \%, 50.17 \%$, $28.17 \%$, 17.17\%, and $16.67 \%$ for Pichia sp., B. subtilis, Gonytrichum sp., green propolis nosodium $06 \mathrm{CH}$, and $C$. carbonica $12 \mathrm{CH}$, respectively. The highest means of dry stem mass among treatments were found in treatments with Pichia sp. and B. subtilis (1.56 and $1.33 \mathrm{~g}$ plant $^{-1}$, respectively).

\subsubsection{Dry Root Mass}

There were significant differences among treatments, evaluation periods, and their interaction for the variable dry root mass, the behavior of the treatments varying according to the time of evaluation (Figure 5). The highest mean dry root mass was observed for treatment with $B$. subtilis, green propolis nosodium $06 \mathrm{CH}$, Gonytrichum sp., Pichia sp., and C. carbonica 
$12 \mathrm{CH}\left(1.44 ; 1.33 ; 1.33 ; 1.33\right.$ and $1.22 \mathrm{~g} \mathrm{plant}^{-1}$, respectively).

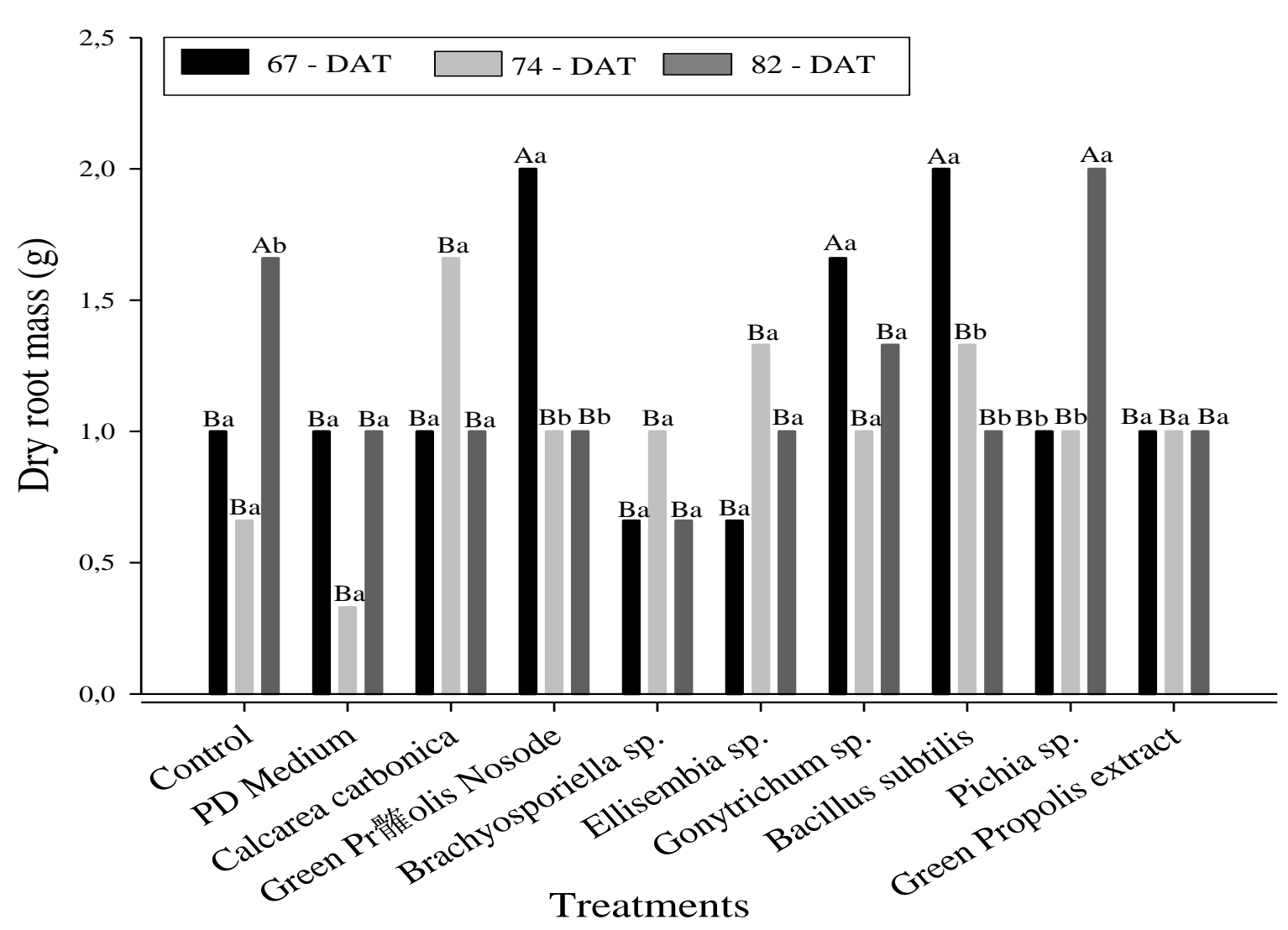

Figure 5. Dry mass (g) of passion fruit root at 67, 74, and 82 (DAT), depending on the application of bioproducts. Distinct capital letter indicate difference $(p<0,05)$ among the treatments in each time period. Distinct lower letters indicate difference $(\mathrm{p}<0,05)$ between

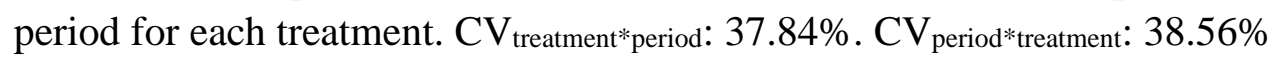

At 67 DAT, treatments with B. subtilis, green propolis nosodium $06 \mathrm{CH}$, and Gonytrichum sp. resulted in a dry root mass increment of $100.00 \%, 100.00 \%$, and $66.00 \%$, respectively, compared with the control; the other treatments did not differ from the control at 67 DAT. At 74 and 82 DAT, there were no significant differences among treatments.

\subsubsection{Total Biomass}

Regarding the total biomass, there were significant differences among treatments, evaluation times, and interaction between both. Data from treatments are presented within evaluation periods (Figure 6). In general, the highest means, regardless of the evaluations, were found for B. subtilis, Pichia sp., and Gonytrichum sp. with the values of $4.78,4.78$ and $4.33 \mathrm{~g}$ plant $^{-1}$, respectively, showing increases of $42.31 \%, 32.82 \%$, and $21.44 \%$, respectively, compared with the control. 


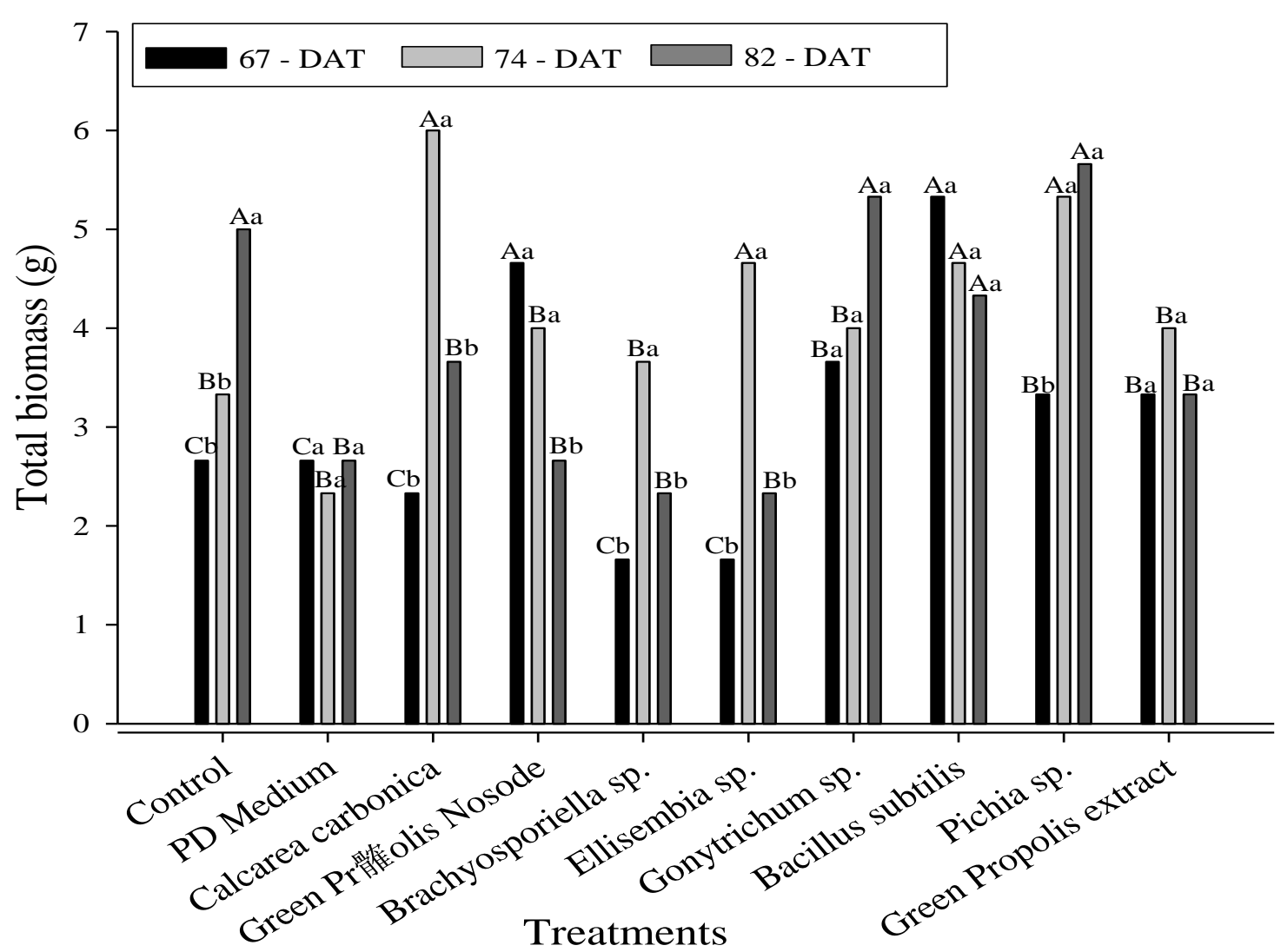

Figure 6. Total biomass (g) of passion fruit plants at 67, 74, and 82 (DAT), depending on the application of bioproducts. Distinct capital letter indicate difference $(p<0,05)$ among the treatments in each time period. Distinct lower letters indicate difference $(p<0,05)$ between

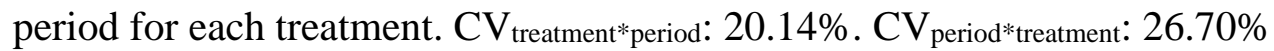

At 67 DAT, B. subtilis and propolis nosodium treatments stood out with an increase of $100.38 \%$ and $75.19 \%$, respectively, compared with the control, followed by Gonytrichum sp., Pichia sp., and green propolis extract, with significant increments of $37.59 \%, 25.19 \%$, and $25.19 \%$, respectively, compared with the control.

At 74 DAT, treatments with $C$. carbonica $12 \mathrm{CH}$, Pichia sp., B. subtilis, and Ellisembia sp. were significantly superior to the others, with an increase of $80.18 \%, 60.06 \%, 39.94 \%$, and $39.94 \%$, respectively, compared with the control. The treatments green propolis nosodium $06 \mathrm{CH}$ and green propolis extract did not differ from the control.

At 82 DAT, treatments with Pichia sp., Gonytrichum sp., and the control differed significantly from the other treatments but did not differ from each other.

\subsection{Area Under the Disease Progress Curve (AUDPC)}

There were no significant differences among treatments in the AUDPC of Lasiodiplodia black rot (Lasiodiplodia theobromae) (Table 1). Cardoso et al. (2009) working with Lasiodiplodia sp. in a greenhouse reported that the infection process was not efficient and that factors generating stresses such as water deficit and/or thermal amplitude could contribute to the disease progress. 
Table 1. Area under the Lasiodiplodia black rot (Lasiodiplodia theobromae) progress curve in passion fruit plants, depending on the application of bioproducts

\begin{tabular}{lc}
\hline Treatments & AUDPC \\
\hline T1-Distilled water & $47.95^{\mathrm{ns}}$ \\
T2-PD culture medium at 20\% & 58.10 \\
T3-Homeopathy Calcarea carbonica 12CHat 20\% & 55.30 \\
T4-Homeopathy Green Propolis nosodium 06CH at 20\% & 37.10 \\
T5-Filtrate of Brachysporiella sp. at 20\% & 42.70 \\
T6-Filtrate of Ellisembia sp. at 20\% & 35.35 \\
T7-Filtrate of Gonytrichum sp. at 20\% & 50.05 \\
T8-Bacillus subtilis at 20\% & 49.00 \\
T9-Filtrate of yeast Pichia sp. at 20\% & 56.00 \\
T10-Green Propolis extract at 0.8\% & 57.40 \\
\hline
\end{tabular}

ns: not significant.

\section{Discussion}

Of the growth components evaluated, such as dry leaf mass, dry root mass, dry stem mass, and total biomass, the treatments with Pichia sp., Gonytrichum sp., C. carbonica $12 \mathrm{CH}$, and B. subtilis presented more satisfactory results compared with other treatments. This was possibly owing to the production of organic compounds, including hormones, amino acids, and enzymes, that regulate respiratory and photosynthetic activity in plants (Hossain, Sultana, 2020). In case of homeopathy treatments, these may be triggering and/or being the precursor of reactions of catabolism and anabolism that may contribute to the development of the plant (Mazón-Suástegui et al. 2019).

Regarding treatment with Pichia sp., the increases in plant growth (Figure 1), leaf area (Figure 2), and total biomass (Figure 6) are related to the adaptability of yeasts to different environments.

Some species of Pichia sp. with stand adverse conditions, growing in stressful environments, and metabolize a large number of carbon and nitrogen sources (Kurtzman; Fell, 1998). In addition to this adaptability, yeasts of the Pichia sp. genus act in the solubilization of nutrients for plants even under stress conditions. When evaluating the efficiency of phosphorus solubilization, Zhu et al. (2012) using P. farinosis under conditions of stress in the environment, such as temperature variation, $\mathrm{pH}$, and salt concentration, showed that this yeast can solubilize increasing amounts of unavailable phosphorus. When these authors tested a biofertilizer enriched with the yeast, a large amount of assimilable phosphorus was made available to soybean plants, thus increasing the total dry mass of plants.

The seedlings subjected to treatment with Gonytrichum sp. showed good performance in terms of plant height (Figure 1), leaf area (Figure 2), and total biomass (Figure 6). This performance may have occurred owing to the interaction of the fungus with the substrate, 
thus providing nutrients and water to the roots of the plants. Microorganisms that can solubilize phosphorus such as Gonytrichum sp. improve plant development because phosphorus in tropical soils is usually in a form not available for plants to absorb (Gomezjurado et al. 2015).

Gomezjurado et al. (2015) evaluated phosphate solubilization capacity of fungi from the Amazon forest and found 21 strains of Ascomycota fungi capable of solubilizing phosphorus, and G. macrocladum was among the strains identified. Laboratory evaluation showed that this same fungus influenced the growth of roots of corn seedling (Zea mays L.) and cowpeas (Vigna unguiculata [L]. Walp), although it does not differ from the control.

Homeopathy can be applied in agriculture to control pests and diseases and increase plant development, for example, by improving and stimulating nutrient absorption. Homeopathy treatment with $C$. carbonica $12 \mathrm{CH}$ included in the experiment acts on the plant by improving calcium absorption, an important nutrient of the cellular constitution. The results of plant height (Figure 1), leaf area (Figure 2), dry leaf mass (Figure 3), dry stem mass (Figure 4), dry root mass (Figure 5), and total biomass (Figure 6) exhibited the best effect on development by applying $C$. carbonica $12 \mathrm{CH}$ homeopathy, with an effect most prominent at 74 DAT for all variables analyzed.

Using the homeopathic drug Sulphur in radish (Raphanus sativus L.) in different formulations, Bonato \& Silva (2003) observed an increase in plant growth variables, as well as an increase in dry mass, possibly owing to the production of phytohormones that play a role in growth.

In a study with beans, using homeopathic medicines including $C$. carbonica, the authors observed an increase in the activity of peroxidase, catalase, chitinase, glucanase, and phytoalexin phaseolin, proving that the homeopathies used in the study have the potential to act as plant defense promoters (Oliveira et al. 2014).

Another factor that interferes with the effect of homeopathy is the formulation used. In the current study, $C$. carbonica was used at $12 \mathrm{CH}$, and the increase in dynamization increases the energy information of homeopathy and can improve the observed performance.

In a study of different dynamizations for homeopathies, Arsenicum album and Sulphur, Bonato et al. (2009) evaluated growth attributes in plants and increase in the concentration of essential mint oil (Mentha arvensis L.). The authors observed an increase in plant height and dry mass of plants and root, however, when using Sulphur in $12 \mathrm{CH}, 24 \mathrm{CH}$, and $30 \mathrm{CH}$ formulations, the increase in dry mass of the plant was inhibited, differing negatively from $6 \mathrm{CH}$ and the control. For the homeopathy Arsenicum album, the dynamizations of $24 \mathrm{CH}$ and $30 \mathrm{CH}$ provided an increase compared with other dynamizations and the control. In the assessment of essential oil concentration, the $24 \mathrm{CH}$ dynamization, in both homeopathies, was responsible for the highest concentrations of essential mint oil.

The treatment with B. subtilis improved plant development, and like other treatments, it mainly improved plant height (Figure 1), leaf area (Figure 2), and total biomass (Figure 6). This performance is related to the ability of this bacteria to associate with plant roots because 
it is classified as a rhizobacteria. It improves nutrient absorption and increases hormone production such as abscisic acid (ABA), indoleacetic acid (IAA), cytokinins, gibberellins, among other phytohormones related to the growth of plant tissues acting on cell division (Arshad; Frankenberger, 1991).

According to Arkhipova et al. (2005), increases of cytokinin, ABA, and IAA in roots and young lettuce plants are linked to the application of $B$. subtilis, which increases the dry weight by $30 \%$.

The production of a biofilm around the plant roots by the bacteria helps protect the roots against phytopathogens present in the soil. Beauregard et al. (2013) verified the interaction of B. subtilis and biofilm production in the roots of Arabidopsis thaliana. The results showed that the plant releases polysaccharides to stimulate the bacteria to produce the biofilm and the polysaccharides act as a glue to adhere to the biofilm.

On data analysis, it is possible to verify that 74 DAT is the most suitable time for transplantation of passion fruit seedlings into the field, being more economical for the producer, owing to the quality of the seedlings as well as a greater probability of resisting adverse environmental conditions and preventing possible diseases and attacks by pests.

The results of AUDPC indicate that the fungus was not able to produce symptoms of the disease, as in a study by Cardoso (2009), on the transmission of L. theobromae via cashew propagule, asymptomatic infection was observed owing to latent action of the fungus; only after the seedlings went to the field under temperature stress, it was possible to observe the symptoms of the disease. This characteristic is important for seedling production because it is necessary to have adequate control of the pathogen so that it is not disseminated to the field.

In a study conducted by Kikuchi et al. (2012) on natural compounds produced by microorganisms, the compound gonytolides isolated from Gonytrichum sp. revealed antiproliferative effects in S2 cells of Drosophila sp., which may contribute to the development of pest control products.

In addition to the latency characteristic of the phytopathogen in the plant, the bioproducts used in this study may have induced the plant's defense system and the production of defense mechanisms, contributing to the development of passion fruit plants, and adding value to the biodiversity of the southern Amazon.

\section{Conclusion}

The application of filtrates of Pichia sp. and Gonytrichum sp., Calcarea carbonica 12CH, and Bacillus. subtilis resulted in better growth and development performance of passion fruit plants, with an improvement of the main morphological attributes over time. Under the experimental conditions of the study, Lasiodiplodia sp. did not express disease symptoms.

\section{References}

Arkhipova, T. N., Veselov, S. U., Melentiev, A. I., \& Martynenko, E. V. (2005). Ability of bacterium Bacillus subtilis to produce cytokinins and to influence the growth and endogenous 
hormone content of lettuce plants. Plant and Soil 272, 201-209. https://doi.org/10.1007/s11104-004-5047-x

Arshad, M., \& Frankenberger, W. T. (1991) Microbial production of plant hormones. In: Keister DL, Cregan PB (eds) The Rhizosphereand Plant Growth. Beltsville Symposia in Agricultural Research. Springer, Dordrecht. https://doi.org/10.1007/978-94-011-3336-4_71

Beauregard, P. B., Chai, Y., Vlamakis, H., Losick, R., \& Kolter, R. (2013).Bacillus subtilis bio film induction by plant polysaccharides. Proceedings of the National Academy of Sciences of the United States of America, 110(17), 1621-1630. https://doi.org/10.1073/pnas.1218984110

Bonato, C. M. (2002). Como funciona a homeopatia. Conselho Regional de Medicina Veterinária - CRMV PR. In: Agroflorestas $O$ “Tao” da produtividade. 5, II.

Bonato, C. M., \& Silva, E. P. da (2003). Effect of the homeopathic solution Sulphur on the growth and productivity of radish. Acta Scientiarum. Agronomy, 25(2), 259-263.

Bonato, C. M., Proença, G. T. de, \& Reis, B. (2009). Homeopathic drugs Arsenicum album and Sulphur affect the growth and essential oil content in mint (Mentha arvensis L.). Acta Scientiarum. Agronomy, (31), 101-105. https://doi.org/10.4025/actasciagron.v31i1.6642

Bonato, C. M. (2010). Homeopatia para o Agricultor - Princípios e Aplicações Práticas. Maringá, PR: Secretaria de Estado de Ciência, Tecnologia e Ensino Superior.

Botrel, D. A., Laborde, M. C. F., Medeiros, F. H. V., Resende, M. L. V., Júnio, P. M. R., Pascholati, S. F., \& Gusmão, L. F. P. (2018). Saprobic fungi as biocontrol agents of halo blight (Pseudomonas syringae pv. garcae) in coffee clones. Coffee Science, 13(3), 283-291. https://doi.org/10.25186/cs.v13i3.1438

BRASIL (2008). Instrução Normativa n. 64 de 18 de dezembro de2008. Ementa: Aprova o Regulamento Técnico para os Sistemas Orgânicos de Produção Animal e Vegetal. Diário Oficial da União. Brasília, Seção 1, p. 21.

Cavalcante, D. R. R., Oliveira, P. S. de, Góis, S. M., Soares, A. F., Cardoso, J. C., Padilha, F. F., \& Albuquerque, R. L. C. de. (2011). Effect of green própolis on oral epithelial dysplasia in rats. Brazilian Journal of Otorhinolaryngology, 77(3), 278-284. https://doi.org/10.1590/S1808-86942011000300002

Cardoso, J. E., Bezerra, M. A., Viana, F. M. P., Sousa, T. R. M., Cysne, A. Q., \& Farias, F. C. (2009). Ocorrência endofítica de Lasiodiplodia theobromae em tecidos de cajueiro e sua transmissão por propágulos. SummaPhytopathologica, 35(4), 262-266. https://doi.org/10.1590/S0100-54052009000400002

Campbell, C. L., \& Madden, L. V. (1990). Introductionto Plant Disease Epidemiology, Wiley, New York, 532 pp.

Cook, R. J., \& Baker, K. F. (1983). The nature and practice of biological control of plant pathogens. St. Paul, Minnesota: The American Phytopathological Society, 539p. 
Costa, A. F. S., Costa, A. N., Ventura, J. A., Fanton, C. J., Lima, I. M., Caetano, L. C. S., \& Santana, E. N. (2008). Recomendaçõestécnicas para o cultivo do maracujazeiro. Vitória, ES:Incaper. 1-51p.

Coutinho, P., \& Bomtempo, J. V. (2011). Roadmap tecnológicoemmatérias-primasrenováveis: uma base para a construção de políticas e estratégias no Brasil. São Paulo: Química nova, 34(5), 910-916. https://doi.org/10.1590/S0100-40422011000500032

Ferreira, D. F. (2019). Sisvar: a computer analysis system to fixed effects split plot type designs. Revista Brasileira De Biometria, 37(4), 529-535. https://doi.org/10.28951/rbb.v37i4.450

FHB (2011). FarmacopeiaHomeopática Brasileira, (3nd ed.). Brasília, DF.

Ghisalbert, I. E. L., Jefferies P. R., \& Lanteri, R. (1977). Potential drugs from própolis. In: Frigerio A, Ghisalberti EL (Ed.) Mass spectrometry in drugs metabolism. New York, Plenum Press, p. 111-130.

Gomezjurado, M. E. G., Abreu, L., Marra, L., Pfenning, L., \& Moreira, F. M. S. (2015). Phosphate solubilization by several genera of saprophytic fungi and its influence on corn and cowpea growth. Journal of Plant Nutrition, 38(5), 675-686. https://doi.org/10.1080/01904167.2014.934480

Hossain, M. D., \& Sultana, F. (2020). ApplicationandMechanismsof Plant GrowthPromoting Fungi (PGPF) for Phytostimulation. In: Das, S. C. OrganicAgriculture, IntechOpen. https://doi.org/10.5772/intechopen.92338

Kikuchi, H., Isobe, M., Kurata, S., Katou, Y., \& Oshima, Y. (2012). New dimeric and monomeric chromanones, gonytolides D-G, isolated from the fungus Gonytrichum sp.

Tetrahedron, 68(31), 6218-6223. https://doi.org/10.1016/j.tet.2012.05.064

Kurtzman, C. P., \& Fell, J. W. (1998). The yeasts, a taxonomic study. 4th ed. New York: Elsevier. 695p.

Mazón-Suástegui, J. M., Ojeda, S. C. M., García, B. M., Avilés, Q. M. A., Abasolo, P. F., Batista, D. S., ... Bonilla, B. M. (2019). Agricultural Homoeopathy: A new insight into organics. In: Moudrý, J., Bernas, J., Mendes, K. F. Sousa, R. N., Teixeira, R. N. Multifunctionality and Impacts of Organic and Conventional Agriculture. https://doi.org/10.5772/intechopen.84482

Oliveira, J. S. B., Maia, A. J., Estrada, K. R. F. S., Bonato, C. M., Carneiro, S. M. T. P. G., \& Picoli, M. H. S. (2014). Activation of biochemical defense mechanisms in bean plants for homeopathic preparations. African Journal of Agricultural Research, 9(11), 971-981. https://doi.org/10.1016/j.chemosphere.2005.12.057

Oliveira, J. S. B., Schwan-Estrada, K. R. F., Bonato, C. M., \& Gomes, S. M. T. P. (2017). Homeopatias de óleos essenciais sobre a germinação de esporos e indução de fitoalexinas. Revista Ciência Agronômica,48, 208-215. 
Oliveira, S. A. B. de, Barbosa, F. R., Andrade, E. A., Ferrarini, S. R., \& Bonaldo, S. M. (2019). Compostos voláteis de fungos conidiais sapróbios da Amazônia Meridional no controle in vitro de fitopatógenos. Summa Phytopathologica, 45(3), 302-307. https://doi.org/10.1590/0100-5405/178478

Park, Y. K., Hikegaki, M., Abreu, J. A. S., \& Alcici, N. M. F. (1998). Estudo da preparação dos extratos de própolis e suas aplicações. Ciência e Tecnologia de Alimentos, 18(3), 313-318. https://doi.org/10.1590/S0101-20611998000300011

Pereira, C. S., Guimarães, R. J., Pozza, E. A., \& da Silva, A. A. (2008). Controle da cercosporiose e da ferrugem do cafeeiro com extrato etanólico de própolis. Ceres, 55(5).

Ploetz, R. C. (2013). Diseases of Tropical Fruit Crops. In Manicom, B., Ruggiero, C., Ploetz, R. C., Goes, A., Diseases of Passion Fruit (pp. 413-441). Florida: CABI Publishing.

Solino, A. J. Da S., Schwan-Estrada, K. R. F., Oliveira, J. S. B., Ribeiro, L. M., \& Saab, M. F. (2017). Accumulation of phytoalexins in beans, soybeans and sorghum by fungal filtrates. Revista Caatinga, 30(4), 1073-1078. https://doi.org/10.1590/1983-21252017v30n429rc

Toledo, M. V., Stangarlin, J. R., \& Bonato, C. M. (2015). Controle da pinta preta e efeito sobre variáveis de crescimento em tomateiro por preparados homeopáticos. Summa Phytopathologica, 41(2), 126-132. https://doi.org/10.1590/0100-5405/1944

Zaidi, S., Usmani, S., Singh, B. R., \& Musarrat, J. (2006). Significance of Bacillus subtilis strain SJ-101 as a bioinoculant for concurrent plant growth promotion and nickel accumulation in Brassica juncea. Chemosphere,64, 991-997. https://doi.org/10.1016/j.chemosphere.2005.12.057

Zhu, H., Sun, L., Zhang, Y., Zhang, X., \& Qiao, J. (2012). Bioresource Technology Conversion of spent mushroom substrate to biofertilizer using a stress-tolerant phosphate-solubilizing Pichia farinose FL7. Bioresource Technology, 111, 410-16. ttps://doi.org/10.1016/j.biortech.2012.02.042

\section{Copyright Disclaimer}

Copyright for this article is retained by the author(s), with first publication rights granted to the journal.

This is an open-access article distributed under the terms and conditions of the Creative Commons Attribution license (http://creativecommons.org/licenses/by/4.0/). 